International Journal of Child, Youth and Family Studies (2019) 10(1): 95-118

DOI: $10.18357 /$ ijcyfs 101201918808

\title{
WE NEED TO GET BETTER AT THIS! PEDAGOGIES FOR TRUTH TELLING ABOUT COLONIAL VIOLENCE
}

\author{
Elizabeth Fast and Marie-Ève Drouin-Gagné
}

\begin{abstract}
This article considers the importance of widespread teaching of colonial histories to future generations of students. The Truth and Reconciliation Commission of Canada's 2015 report, Calls to Action, asserts that the lack of historical knowledge among most Canadians has serious consequences for Indigenous peoples, and for Canada as a whole. Using the Responses to Interpersonal Violence framework, this paper explores the capacity of educators to teach colonial histories in a way that indicates supportive social responses and a recognition of the ongoing colonial violence lived by Indigenous peoples in Canada. It also makes recommendations on core principles of teaching colonial histories to Indigenous and non-Indigenous students in a responsible way that respects the intentions of the Truth and Reconciliation Commission.
\end{abstract}

Keywords: teaching, decolonization, colonial histories, Truth and Reconciliation, response-based practice

Elizabeth Fast PhD, Métis (corresponding author) is an Assistant Professor in the Department of Applied Human Sciences, Concordia University, Vanier Extension, 7141 Sherbrooke West, Montreal, QC H4B 1R6. Email: Elizabeth.fast@ concordia.ca

Marie-Ève Drouin-Gagné is a doctoral candidate in the Department of Sociology, Concordia University, 1455 Boulevard de Maisonneuve, Montreal, QC H3G 1M8. Email: marie-eve.drouin.gagne@concordia.ca 
The Truth and Reconciliation Commission of Canada (TRC) was established in June of 2008 as one of five measures instituted by the Indian Residential Schools Settlement Agreement. During the six years that the Commission was active, it travelled throughout Canada to hear from individuals who had been taken from their families as children and placed in residential schools. Residential schools were part of a set of policies meant to try and assimilate Indigenous children by removing them from their families, communities, and cultures and forcing them to abandon all aspects of their cultures for fear of punishment and abuse (Milloy, 1996). The TRC's final report and Calls to Action were released in December 2015 and are available on the National Centre for Truth and Reconciliation website (http://nctr.ca/reports.php). The Commission's focus on truth determination was intended to lay the foundation for the important question of reconciliation: Now that we know about residential schools and their legacy, what do we do about it?

In the TRC's (2015) report Calls to Action, under the heading "Education for Reconciliation", call to action number 62 states:

We call upon the federal, provincial, and territorial governments, in consultation and collaboration with Survivors, Aboriginal peoples, and educators, to:

- Make age-appropriate curriculum on residential schools, Treaties, and Aboriginal peoples' historical and contemporary contributions to Canada a mandatory education requirement for Kindergarten to Grade Twelve students.

- Provide the necessary funding to post-secondary institutions to educate teachers on how to integrate Indigenous knowledge and teaching methods into classrooms.

Although these recommendations are critical to increasing awareness and knowledge of Canada's colonial past and its ongoing impacts, there are a few potential barriers to a full implementation of the recommendations. First of all, it will take time for post-secondary institutions to train teachers; thus, even if students do begin to learn about residential schools, there is no guarantee that their teachers have received this education. Teachers may then avoid introducing Indigenous knowledges and pedagogies into the classroom because they don't know where to begin and are intimidated by the prospect of facilitating difficult discussions. Second, as a result of our combined experience teaching undergraduate students and what they have relayed about the reality in Quebec and other eastern provinces, we have become aware that students are coming into post-secondary settings with little or no knowledge of Indigenous histories and contemporary realities.

In addition, the language of "reconciliation" has been criticized as a settler "move to innocence" (Tuck \& Yang, 2012), which eases the guilt for the settler society of benefitting from Indigenous peoples' erasure, dispossession, and assimilation, but without addressing the ongoing colonial violence. Tuck and Yang (2012) define colonial violence as the structure of our society, 
which disrupts Indigenous relationships to land by imposing on it a property and ownership relationship (p. 5), resulting in the dispossession and imposed poverty of Indigenous peoples, as well as disruption of Indigenous "epistemological, ontological, and cosmological relationship to land [which] are interred, indeed made pre-modern and backward" (p. 5). In this process, there is a "profound epistemic, ontological, cosmological violence ... reasserted each day of occupation" (p. 5) that is not resolved or addressed simply by teaching critical perspectives on colonialism. Therefore, there is a need to explore and implement models and frameworks that can orient our teaching so that we get better at teaching colonial history and integrating Indigenous perspectives, knowledges, and teaching methods in our classrooms.

The Responses to Interpersonal Violence (RIV) framework aims to reshape the way that we think about responses to interpersonal violence. Traditionally, in describing and understanding acts of interpersonal violence, the focus has been on the violent act as such and the victim is constructed as relatively passive in the interaction (Coates \& Wade, 2007). As a consequence, research has tended to overlook the series of responses to the violence. However, using the RIV framework, discursive concealing of violence, obscuring of responsibility, concealing of resistance, and victim blaming can be avoided by exposing the full extent of the violence, clarifying responsibility, revealing resistance, and aligning with the victim or victims (Coates \& Wade, 2007).

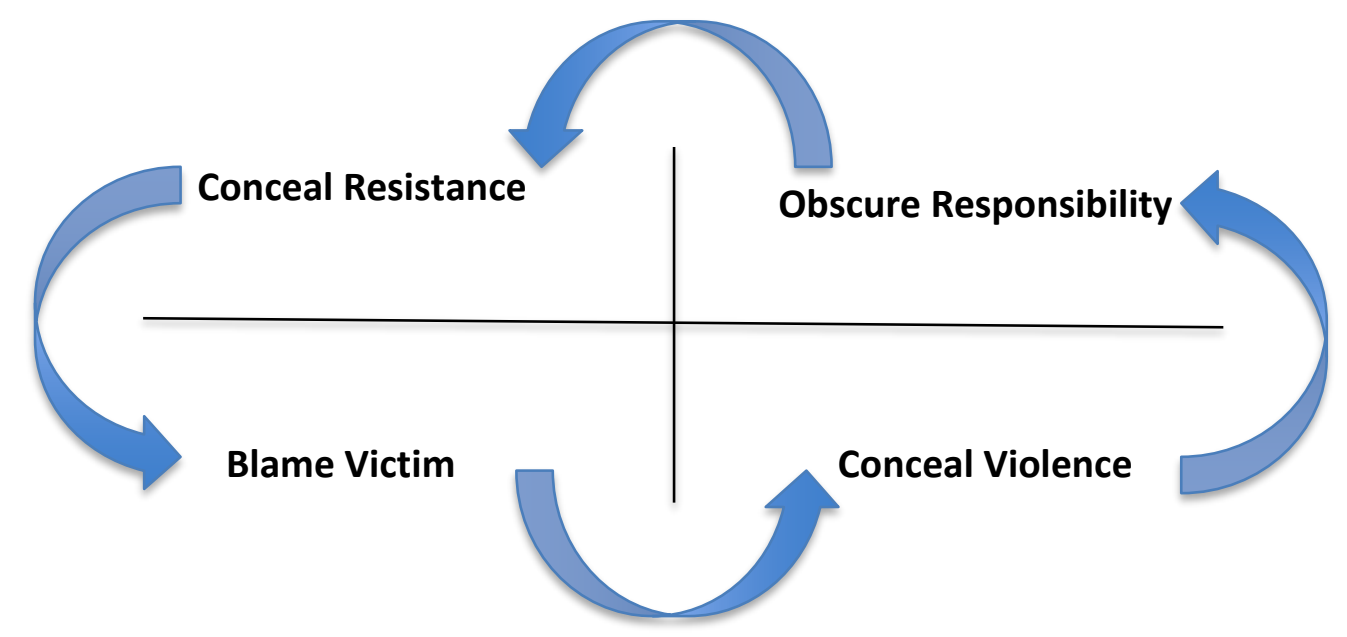

Figure 1. Four operations of discourse on violence that the RIV framework avoids (Coates \& Wade, 2007).

By broadening the study of interpersonal violence to include the responses it evokes, the RIV framework is helpful in reframing the way that colonial histories are taught. On one hand, it allows the unveiling of violence as a deliberate, social, and unilateral reality, and, on the other hand, the recognition that resistance to colonial violence is ever-present. This paper will draw from the RIV framework, in dialogue with existing literature on decolonizing and Indigenous pedagogies, to discuss how educators can take up the challenges of teaching colonial histories in ways that promote cultural safety in the classroom. For the purposes of this paper, the analysis will 
be on the social actors' (i.e., school teachers, university and college professors) responses to colonial violence and how these responses are then passed on or taught to students. We will then use our own experiences to show how anti-racist principles might be applied when teaching difficult topics, particularly pertaining to Indigenous colonial histories.

\section{Literature Review: Why Teach Colonial Histories and Ongoing Colonial Violence?}

\section{To Avoid Concealing Violence: Truth-Telling and Exposing the Full Extent of the Violence}

As the RIV framework puts it, a first step in addressing responses to violence is to obtain accurate accounts of the violence from all sides, exposing its full extent (Kinewesquao \& Wade, 2009). This also applies to colonial violence, and various authors have written about the importance of teaching colonial history in the classroom, as a way to render visible, explain, and problematize the historical and ongoing unfairness of our social structures (Tuck \& Yang, 2012, p. 2; Waziyatawin \& Yellow Bird, 2005, p. 3). The Canadian ongoing colonial reality implies serious continuous effects on Indigenous peoples, such as violence, ethnostress, and historical trauma (Cote-Meek, 2014, pp. 25-31). As the TRC also calls for the repudiation of concepts "used to justify European sovereignty over Indigenous lands and peoples such as the Doctrine of Discovery" (TRC, 2015 , p. 5) ${ }^{1}$, we need to understand this colonial past in order to change the present and repudiate the concepts and actions that are part of the colonial violence. As Waziyatawin and Yellow Bird (2005) put it, "The first step towards decolonization, then, is to question the legitimacy of colonization" (p. 3), which, of course, implies learning about the processes of colonization.

Acknowledging and validating the history of oppression and colonization on which the country was created at the expense of Indigenous nations is seen as an important step in healing and decolonization (Battiste, 1998). More precisely, truth-telling has to happen in ways that allow us to understand past events, such as the imposition of residential schools, as part of a current

\footnotetext{
${ }^{1}$ The Doctrine of Discovery comes from a legal opinion articulated by the US court (Marshall's opinion in Johnson V. M'Intosh, 1823) following an old European principle of international law that proclaimed the right of European nations to own the lands they "discovered" and conquered, at the expense of Indigenous sovereignty (Miller, 2011; Miller, Ruru, Behrendt, \& Lindberg, 2012). The concepts of land titles articulated in this legal doctrine were based on two fundamental ideas of a supposed Western superiority: Europeans were superior because they were Christian and because they were "civilized"; therefore, settlers were bringing civilization to Indigenous nations. Based on these conceptions, settler societies took upon themselves to "educate" Indigenous Peoples following their ideas of religion and civilization (Lomawaima, 1999; Lomawaima \& McCarty, 2006). Miller et al. (2012), in accord with Williams (1988, 1990, 2012a, 2012b) and many Indigenous activists at the United Nations (Frichner, 2010; UN Permanent Forum on Indigenous Issues, 2010, 2012), present the Doctrine of Discovery as the foundation of the current laws regulating relations between Indigenous Peoples and settler states like the United States, Canada, Australia, and New Zealand, as well as the international recognition of these governments' sovereignty over Indigenous Peoples and lands. The idea of Western superiority is maintained today with concepts such as progress, and how Indigenous Peoples are seen as obstacles to this progress. As the legitimacy of our states in the Americas relies on the Doctrine of Discovery, it implies the subordination of Indigenous Peoples' rights, life projects, relationships to the land, and political aspirations.
} 
International Journal of Child, Youth and Family Studies (2019) 10(1): 95-118

colonial relationship still to be dismantled today (Regan, 2010, p. 42), just as we still have to effectively displace the cognitive imperialism that has been imposed on Indigenous peoples through education (Battiste, 2013, p. 158). In that sense, the colonial experience has to be spoken about because it offers an explanation for the past and present violence that Indigenous peoples have faced and still face, as well as a way to understand resistance and possible futures (CoteMeek, 2014, p. 25). Simply put, and following core principles of any "truth and reconciliation" process, telling the truth is part of the healing process, and it is especially important when the truth includes past and present experiences of suffering that have been diminished, silenced, or ignored (Waziyatawin, 2005, p. 193).

Furthermore, an important motivation for teaching the history of colonial relations between Indigenous and settler societies is the impact it can have for Indigenous students. For Indigenous students, revealing the abuses of the past and their ongoing impacts can be painful; however, it can also be uplifting or empowering by validating their experiences and offering an explanation of the current continuous or intergenerational violence (Cote-Meek, 2014; Evans-Campbell, 2008; Fast \& Nutton, 2014). Meanwhile, for students and professors coming from a settler-privilege perspective, the teaching of colonial history and its current impacts on our society as well as the confrontation and elimination of racism can be very challenging, because it questions the national image that they have built as Canadians (Battiste, 2013, p. 125), to which they may have very different levels of commitment. Nevertheless, however positive students' and professors' image of Canada might be, it is important to question it precisely because this positive narrative is the one that justifies the colonial violence over Indigenous peoples, rationalizing the taking of Indigenous lands and resources. Hence, the challenging nature of truth-telling, and the resistance and guilt that it might encounter, cannot be an excuse to avoid the responsibilities that any "reconciliation" would entail (Regan, 2010).

\section{To Avoid "Ignorance" and "Innocence" Moves that Obscure Responsibility: Clarifying Responsibilities}

Clarifying who is responsible for the violence, and taking responsibility for it is an important part of the teaching of colonial histories in a RIV framework. In the context of colonial history teaching, this does not mean that the identity crisis potentially experienced by non-Native students, and the difficulty they might encounter throughout the unsettling process of learning about colonialism, should not be addressed. But a clear understanding of who is the survivor and who is in position to continue or stop the violence must be established. A good example of ignorance as colonial strategy is to ask to "put behind us" the colonial violence as something of the past ("get over it"), rather than "examining the cultural attitudes that influence understanding of the responsibility that Canadian society bears" for colonial violence (Regan, 2010, p. 42). In that sense, in the classroom, it is crucial to establish an understanding and acknowledgement of the racial burden and ongoing violence lived by Indigenous students (Cote-Meek, 2014). This understanding cannot occur solely through lectures and readings, but requires holistic pedagogical approaches that will allow a transformation in the students. This is why many authors have argued 
for the use of Indigenous pedagogies in the classroom in order to address difficult materials and to achieve a transformative, unsettling education towards decolonization (Battiste, 2013; Cote-Meek, 2014; Grande, San Pedro, \& Windchief, 2015; Henry, 2014; Irlbacher-Fox, 2014; Regan, 2010; Snelgrove, Kaur Dhamoon, \& Corntassel, 2014; Waziyatawin \& Yellow Bird, 2005; Wildcat, McDonald, Irlbacher-Fox, \& Coulthard, 2014).

However well intentioned, educators might feel unsure as to where to begin. For example, the Department of Applied Human Sciences at Concordia University held a Teaching Day on "Responding to the TRC Calls to Action" on April 27, 2015, including a workshop on Contemporary Indigenous Identities in Canada, with Suzanne Keeptwo, and debriefing and reflection sessions led by a teaching team comprised of members of the department (Dr. Elizabeth Fast, Dr. Rosemary Reilly, and Dr. Hilary Rose). Part of the debriefing and reflection was centred on asking participants about their needs for support when it comes to integrating Indigenous content in their classrooms. One of the main findings that came out of these discussions is that most faculty had little knowledge of historical forces that impact the living conditions of Indigenous peoples in Canada, and little confidence in their grasp of such basics as proper terminology. They felt lacking in the background knowledge to effectively manage discussions in the classroom. In that sense, there is a profound contradiction between the fact that we encourage teachers to include Indigenous content and colonial history in their curriculum, and the reality that "the majority of teachers, like the majority of Canadians, have a limited understanding of Aboriginal people, history, and culture; rather their understanding is informed by dominant discourses" (Dion, 2007, p. 330). There is thus a need to find ways for professors to transform the way they relate to Canadian colonial history, and the way they understand Indigenous peoples and their relations with Canada, before they can teach their students how to do so.

This lack of preparedness, lack of training, and the gap in faculty's actual knowledge of colonial history and Indigenous peoples' history can serve as a barrier to inclusion in course content, leading to the thought that it is better to avoid the subject than to approach it in a wrong way. However, using our ignorance as an excuse to absolve ourselves from the "responsibility of addressing our shared colonial history" (Regan, 2010, p. 33) is a "move to innocence" (Tuck \& Yang, 2012) that only perpetuates colonial violence. "Violent innocence" protects individuals, organizations, institutions, and society at large from uncomfortable truths (Regan, 2010). CoteMeek (2014) stressed the responsibility of teachers when it comes to learning difficult knowledges: "Educators have a pedagogical and ethical responsibility to set the tone and context of the classroom experience where students may be required to bear witness to historical trauma" (p. 150). In an academic context that "remains founded on epistemological practices and traditions that are selective and exclusionary", it is the responsibility not only of the teachers but also the entire educational institution to overcome the "sanctioned ignorance of the academy at large" (Kuokkanen, 2007, p. 1).

In this regard, we need to overcome the "scarcity" discourse that predominates in the academy regarding available resources such as Indigenous authors, information about Indigenous 
International Journal of Child, Youth and Family Studies (2019) 10(1): 95-118

peoples' histories and cultures, and perspectives on colonial histories. There are far more articles, books, films, websites, blogs, and community resources available out there than most teachers know about, and the oft-heard statement that there are no Indigenous authors in a given discipline only contributes to the violent erasure of Indigenous peoples' intellectual traditions and contributions to the academy.

\section{To Avoid Concealing Resistance: Bringing Awareness to Ever-Present Indigenous Knowledges and Pedagogies}

Negating the intellectual and pedagogical production of Indigenous peoples in the academy, or not alluding to it when teaching colonial histories, conceals Indigenous resistance and frames Indigenous peoples in the role of passive victims in the colonial process. Following the RIV framework, however, highlighting the ever-present Indigenous resistance to colonial violence should be a priority. Similarly, Tuck and Yang (2012) warned against using a model if it "recenters whiteness, it resettles theory, it extends innocence to the settler, it entertains a settler future" (p. 3). Rather, we should turn to Indigenous models of teaching colonial histories. Done properly, this type of colonial history teaching can be uplifting for Indigenous students in highlighting resistances to colonialism, both in the past and for the future (Cote-Meek, 2014). Table 1 presents some of the existing practices that are achieving this kind of transformation through consideration of colonial history and Indigenous perspectives, and from which one could draw inspiration for their own practice.

Table 1 presents different avenues to teaching colonial history that are not exclusive of each other but complementary, and can be built upon. Among the many steps that we can begin to take in our classrooms are: making space in the classroom for alternative accounts by Indigenous voices (texts, videos, music, guest speakers, etc.) ${ }^{2}$; fostering a critical reflection about one's responses to mainstream representations of Indigenous peoples and history; incorporating approaches that aim at solidarity, and at resistance to dominant discourses and practices; and creating the space necessary for Indigenous resurgence. Without expecting that teaching practices can be changed from one day to the next, the existing models provide good starting points.

Table 1 Selected Models to Address Colonial History in Education

\footnotetext{
${ }^{2}$ Kovach, Carriere, Montgomery, Barrett, and Gilles (2015) mentioned that there is a wide variety of course material tapping into community resources (such as grassroots videos and websites) that can serve to give students a "wider picture of Indigenous peoples' experience with colonialism and what they are doing about it” (p. 72).
} 


\begin{tabular}{|c|c|c|c|}
\hline Author and reference & Description of approach & Main objectives & Means employed \\
\hline $\begin{array}{l}\text { Bryan M. J. Brayboy } \\
(2005) \\
\text { "Tribal Critical Race } \\
\text { Theory" }\end{array}$ & $\begin{array}{l}\text { Make sense of } \\
\text { Indigenous peoples" } \\
\text { identity in terms of: } \\
\text { (a) the problems } \\
\text { encountered by } \\
\text { "American Indians" in } \\
\text { educational institutions; } \\
\text { (b) the educational } \\
\text { programs that are in place } \\
\text { to uniquely serve } \\
\text { American Indian } \\
\text { communities; and (c) the } \\
\text { complicated relationship } \\
\text { between "American } \\
\text { Indians" and the United } \\
\text { States } \\
\text { government. federal }\end{array}$ & $\begin{array}{l}\text { Unveiling the endemic colonization that } \\
\text { is present in American society and its } \\
\text { institutions, including knowledge } \\
\text { institutions (universities), and in } \\
\text { policies. Addressing the impacts of this } \\
\text { colonization on Indigenous identity } \\
\text { (marginalization, racialization). } \\
\text { Addressing the resistance to Indigenous } \\
\text { peoples projects of sovereignty, } \\
\text { autonomy, and self-determination. }\end{array}$ & $\begin{array}{l}\text { Resistance to assimilation } \\
\text { through maintaining and } \\
\text { adapting Indigenous identity } \\
\text { and cultural integrity through } \\
\text { self-education, Indigenous } \\
\text { ways of knowing and values, } \\
\text { and Indigenous sources of } \\
\text { data and theory in stories and } \\
\text { oral knowledge. } \\
\text { Addressing stories as means } \\
\text { of resistance and survivance } \\
\text { of Indigenous knowledges. }\end{array}$ \\
\hline $\begin{array}{lr}\text { Susan Dion (2007) } \\
\text { "Disrupting Molded } \\
\text { Images: Identities, } \\
\text { responsibilities and } \\
\text { relationships } \\
\text { teachers } \\
\text { indigenous } \\
\text { material" }\end{array}$ & $\begin{array}{l}\text { Remembrance approach: } \\
\text { The students recognize } \\
\text { their investments in } \\
\text { relationships structured } \\
\text { by particular ways of } \\
\text { knowing Aboriginal } \\
\text { people. }\end{array}$ & $\begin{array}{l}\text { To counter stereotyping and other } \\
\text { negative effects of the "cultural } \\
\text { difference" approach. } \\
\text { Raising awareness of the ways in which } \\
\text { the identities of both Aboriginal and } \\
\text { non-Aboriginal people in Canada have } \\
\text { been shaped by the colonial encounter } \\
\text { and its aftermath. }\end{array}$ & $\begin{array}{l}\text { Dialogue between students, } \\
\text { incorporating their own } \\
\text { experiences and memories; } \\
\text { Indigenous texts and } \\
\text { productions. }\end{array}$ \\
\hline $\begin{array}{l}\text { Stephanie } \\
\text { Fox }(2014) \\
\text { "Traditional } \\
\text { knowledge, } \\
\text { existence and co- } \\
\text { resistance" }\end{array}$ & $\begin{array}{l}\text { Co-resistance for co- } \\
\text { existence: Resistance to } \\
\text { injustices as the basis of } \\
\text { the relationship. }\end{array}$ & $\begin{array}{l}\text { Redefining the so-called "Indian } \\
\text { problem" into the "settler" or "privilege" } \\
\text { problem. } \\
\text { Refusing to collaborate in maintaining } \\
\text { injustice as the basis of the relationship } \\
\text { between the state and Indigenous } \\
\text { peoples. }\end{array}$ & $\begin{array}{l}\text { Deconstructing issues in ways } \\
\text { that centre settler privilege as } \\
\text { the focus of analysis instead of } \\
\text { the usual mainstream } \\
\text { highlighting of Indigenous } \\
\text { "difference" from a settler- } \\
\text { based norm. }\end{array}$ \\
\hline $\begin{array}{l}\text { Corey Snelgore, Rita } \\
\text { Kaur Dhamoon, and } \\
\text { Jeff Corntassel (2014) } \\
\text { "Unsettling settler } \\
\text { colonialism: The } \\
\text { discourse and politics } \\
\text { of settlers, and } \\
\text { solidarity with } \\
\text { Indigenous nations" }\end{array}$ & $\begin{array}{l}\text { Indigenous resurgence: } \\
\text { Responsibility-based } \\
\text { ethic of truth-telling to } \\
\text { identify and act upon new } \\
\text { pathways to Indigenous } \\
\text { resurgence. }\end{array}$ & $\begin{array}{l}\text { Restoration and regeneration of } \\
\text { Indigenous nationhood. } \\
\text { Repatriation of Indigenous life and land. } \\
\text { To call for justice and the return of stolen } \\
\text { lands and waterways; to acknowledge } \\
\text { their special relationships with } \\
\text { Indigenous peoples. }\end{array}$ & $\begin{array}{l}\text { Relational analysis of colonial } \\
\text { issues (instead of one- } \\
\text { dimensional analysis based on } \\
\text { the settler). } \\
\text { Place-based solidarity: } \\
\text { engagement with the literal } \\
\text { and stolen ground on which } \\
\text { people stand and upon which } \\
\text { they come together. }\end{array}$ \\
\hline
\end{tabular}

The common thread among the models presented here is that, while recognizing the importance of teaching colonial history and the difficult materials this entails, these approaches 
International Journal of Child, Youth and Family Studies (2019) 10(1): 95-118

also incorporate hope (Regan, 2010) by presenting Indigenous responses to colonial violence and oppression. These responses must be included in education about colonial history so as to present Indigenous peoples as an active part of history and contemporary society, to which they contribute in different ways, including their resistance to colonialism. In that sense, Indigenous frameworks, perspectives, knowledges, experiences, and history need to be at the centre of the ideas presented when addressing colonial violence in the classroom, and at the centre of the pedagogical models to do so, if we want to move past the status quo in settler-Indigenous nations relationships and build new, decolonizing, alliances.

\section{To Avoid Blaming the Victims: Aligning with Survivors and Building Cultural Safety}

Acknowledging Indigenous perspectives on colonial histories and Indigenous resistance to colonial violence allows us, by following the RIV framework, to align ourselves with the "victims" (or rather, survivors) of the violence, thus breaking the cycle of victim blaming. In that sense, for teachers in mainstream institutions and programs, beginning to interrogate their position "as colonizer-perpetrator and colonizer-ally" (Regan, 2010, p. 27) is a first step towards truth-telling and the starting place for a dialogue that encompasses both the survivor and the perpetrator of colonial violence (Regan, 2010, p. 42). However, these alliance strategies need also to be assessed in terms of the dignity and safety they provide for Indigenous peoples in the academy, to ensure they do not perpetrate a discourse in which the survivors are blamed.

For example, many models of support for Indigenous students in higher education rely upon ideas and cultural models in which Indigenous peoples are "othered", becoming special cases in the mainstream system, or in which the difference between Indigenous and mainstream culture is identified as a risk. These deficit models eventually turn into victim blaming devices. For example, Cote-Meek (2014) argues against the deficit models that maintain racial and cultural hierarchies, making Indigenous peoples' culture the reason for their failure in the system (p. 90). Battiste (2013) identifies this "cultural difference" answer as very common among white students and professors to explain inequity issues (incarceration rates, educational outcomes, etc.), and she thus suggests models that allow us to gradually move away from "Canada's response to difference to a course in anti-racism and anti-oppressive education" (Battiste, 2013, p. 127). As Cote-Meek (2014) put it, "An anti-colonial framework brings to the centre Indigenous worldviews while still identifying the enormous impact that colonization plays in the lives of Aboriginal peoples" (p. 140). In other words, rather than learning about Indigenous peoples as "others", unsettling pedagogy starts with the idea of learning from the other (Regan, 2010). In that sense, most of the positive approaches to transformative education are about: finding a balance between critical approaches; centring Indigenous knowledges; employing holistic pedagogies that address not only the intellectual dimension, but also the emotional and physical dimensions of learning; and honouring the individual voices of students (Cote-Meek, 2014, p. 90).

The idea of centring Indigenous worldviews and knowledges in the academy context has increasingly been articulated by Canadian universities under the principle of "Indigenizing the 
academy", described as "a conscious effort to bring indigenous people, as well as their philosophies and cultures, into strategic plans, governance roles, academics, research and recruitment" (MacDonald, 2016, para. 4). This process takes a variety of forms across the country, comprising, among other things, the creation of campus spaces and symbols (including events and powwows), academic programs and resources, and research chairs and projects. While this process has often been accompanied, in the past decade or so, by a deeper reflection on Canadian universities' relationships with Indigenous peoples, the meaning of "Indigenizing the academy" has yet to be defined (Canadian Association of University Teachers / Association canadienne des professeures et professeurs d'université [CAUT/ACPPU], 2016, p. A5). In formulating a definition, moves to innocence must be avoided in order to truly align universities with Indigenous peoples' resistance to colonialism. In that sense, Newhouse (2016) mentioned that the cultural representation of Indigenous peoples in the academy is not enough: real Indigenization of the universities needs to address the academy work, which is "about knowledge and its production and transmission from one generation to another" (p. A2). The goal should thus be to bring Indigenous knowledges to the research and teaching that happens in universities (both through academic literature and through Indigenous knowledge holders becoming part of the academy), and to spread Indigenous knowledges to all applicable disciplines (not just Indigenous studies, but political sciences, philosophy, environmental studies, etc.).

In the same spirit, Universities Canada's 13 principles on Indigenous education were crafted with the idea that "the cohabitation of Western science and Indigenous knowledge on campuses has the power of opening a dialogue among cultures and enhancing our shared knowledge" (Murphy \& Robitaille, 2015, para. 4). Still, in order for this dialogue in mainstream universities to become a real conversation that breaks the power dynamics implied in the existing colonial relationship, and to create an ethical space of engagement with Indigenous peoples (Ermine, 2007), it seems necessary to look at the models already developed in the "Indigenous academy" (Indigenous programs and institutions of higher education). Hence, Table 2 presents some directions for Indigenous education that we think should be taken into consideration when thinking about "Indigenizing the academy". 
International Journal of Child, Youth and Family Studies (2019) 10(1): 95-118

Table 2 Selected Models of Indigenous Approaches to Education

\begin{tabular}{|c|c|c|c|}
\hline Model (authors) & Description of model & Main objectives & Means employed \\
\hline $\begin{array}{l}\text { Storytelling, storying, } \\
\text { and counter-stories } \\
\text { (Grande et al., 2015) }\end{array}$ & $\begin{array}{l}\text { Indigenous voices and } \\
\text { stories, as well as } \\
\text { Indigenous histories and } \\
\text { Indigenous perspectives } \\
\text { on histories, as a } \\
\text { response to colonial } \\
\text { history and colonial } \\
\text { violence. }\end{array}$ & $\begin{array}{l}\text { Remembrance: Looking at } \\
\text { one's community history, } \\
\text { remembering Indigenous } \\
\text { knowledges, and maintaining } \\
\text { Indigenous philosophies. } \\
\text { Reclamation: Taking back } \\
\text { spaces, places, and } \\
\text { perspectives; reconnecting. } \\
\text { Regeneration: Moving } \\
\text { forward as contemporary } \\
\text { peoples, based on traditional } \\
\text { values. }\end{array}$ & $\begin{array}{l}\text { Paired with remembering } \\
\text { the history of colonialism } \\
\text { and recognizing its effects, } \\
\text { the authors propose a way } \\
\text { to answer and resist the } \\
\text { colonial legacy through } \\
\text { Indigenous stories. } \\
\text { Storytelling of ancestral } \\
\text { and contemporary histories } \\
\text { in the schooling process } \\
\text { (Chi'XapKaid, 2005). }\end{array}$ \\
\hline $\begin{array}{l}\text { Indigenous community- } \\
\text { based pedagogy } \\
\text { (Ball, 2007; García, } \\
\text { Lozano, Olivera, \& } \\
\text { Ruiz, 2004; McCarthy } \\
\& \text { Lee, 2014; Urrieta, } \\
\text { 2013) }\end{array}$ & $\begin{array}{l}\text { Education that respects } \\
\text { Indigenous sovereignty, } \\
\text { and is accountable to } \\
\text { Indigenous communities } \\
\text { (McCarthy \& Lee, } \\
\text { 2014). The knowledges } \\
\text { include daily, complex, } \\
\text { relational, and } \\
\text { reciprocal relationships } \\
\text { in family and } \\
\text { community life (Urrieta, } \\
\text { 2013), and are } \\
\text { transmitted in those } \\
\text { community and family } \\
\text { settings (García et al., } \\
\text { 2004). }\end{array}$ & 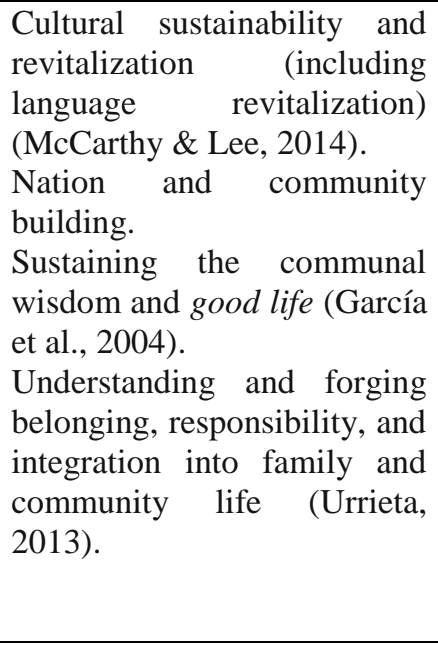 & $\begin{array}{l}\text { Community-based } \\
\text { education partnerships } \\
\text { between First Nations and } \\
\text { postsecondary institutions } \\
\text { (Ball, 2007). } \\
\text { Learning by intent } \\
\text { community participation } \\
\text { (Urrieta, 2013). } \\
\text { Learning communities and } \\
\text { learning through } \\
\text { community experiences } \\
\text { (García et al., 2004). } \\
\text { Community-based } \\
\text { accountability (McCarthy } \\
\text { \& Lee, 2014). }\end{array}$ \\
\hline $\begin{array}{l}\text { Place-based and land- } \\
\text { based pedagogy } \\
\text { (Henry, 2014; } \\
\text { Irlbacher-Fox, 2014; } \\
\text { Wildcat et al., 2014) }\end{array}$ & $\begin{array}{l}\text { The transmission of } \\
\text { knowledge about the } \\
\text { forms of governance, } \\
\text { ethics, and philosophies } \\
\text { that arise from } \\
\text { relationships on the land } \\
\text { (Wildcat et al., 2014). } \\
\text { Reinserting people into } \\
\text { relationships with and } \\
\text { on the land, within } \\
\text { frameworks of } \\
\text { Indigenous intelligence, } \\
\text { as a mode of education } \\
\text { (Wildcat et al., 2014). }\end{array}$ & $\begin{array}{l}\text { Reinhabitation and } \\
\text { decolonization (Henry, 2014). } \\
\text { Privilege refusal and reversal } \\
\text { (Irlbacher-Fox, 2014). } \\
\text { Direct contestation to settler } \\
\text { colonialism and resurgence of } \\
\text { Indigenous life and } \\
\text { Indigenous claims to land } \\
\text { (Wildcat et al., 2014). }\end{array}$ & $\begin{array}{l}\text { Learn forgotten or unheard } \\
\text { Aboriginal, immigrant, and } \\
\text { settler histories in their } \\
\text { neighbourhood, through } \\
\text { arts-based approaches and } \\
\text { engagement with specific } \\
\text { communities } \\
\text { organizations } \\
\text { 2014). } \\
\text { In Indigenous communities } \\
\text { and on Indigenous land, } \\
\text { positioning non- } \\
\text { Indigenous individuals as } \\
\text { students of, and dependent } \\
\text { on, Indigenous peoples, } \\
\text { which reverses the usual } \\
\text { power dynamics } \\
\text { (Irlbacher-Fox, 2014). }\end{array}$ \\
\hline
\end{tabular}

The few models presented here are just some examples of Indigenous approaches to education, going from critical stances resisting assimilation and colonization, to remembering, reclaiming, and regenerating Indigenous cultures, languages, knowledges, and sovereignty, to 
rebuilding Indigenous communities and relationships to the land. We could add to these models some key shared features of Indigenous knowledges, including the use of story as a valuable medium; the importance of place and connection to local lands and land wisdom, learning about and respecting local protocols, the integral role of Elders as knowledge holders, valuing relationality, and the practice of teaching through Indigenous embodiment (Kovach et al., 2015, pp. 35-37). The underlying goal, however, when following the RIV framework, is to align with Indigenous peoples' experiences of, and responses to, colonial violence.

To this end, it is possible to analyze the three models presented in Table 2, and the key features of Indigenous knowledges, in relation to three important decolonizing projects of the Indigenous academy. First, Indigenous programs and institutions of higher education present a restorying of national histories, and thus they challenge mainstream society's assumptions. They uncover Western traditions of civilization and colonization, presenting alternative narratives to the history of the West and of sciences currently taught in school, and they create space for Indigenous history and knowledges, which are so often ignored. Second, by focusing on Indigenous communities - their cultural and intellectual productions, their life projects, their current experiences, and their self-determination - the Indigenous academy, as "an active sense of presence over absence, deracination, and oblivion", is a manifestation of native "survivance" (Vizenor, 2008, p. 1). Finally, by reestablishing the relationship with the land through place and land-based pedagogy, the Indigenous academy participates in Indigenous resurgence (Alfred \& Corntassel, 2005) as a way of "reconnecting with homelands, cultures, and communities" (Corntassel, 2012, p. 97). In order to align with Indigenous peoples' responses to ongoing colonial violence, mainstream academia must find ways to support these three decolonizing projects.

Establishing solidarity with these processes in the classrooms may become very complex once we acknowledge the "incommensurability" of "settler and Indigenous sovereignty and futurity" (Tuck \& Yang, 2012, p. 35), but ideas of differences, uncommonality, and difficult contact need to exist, rather than ideas of inclusion, integration, and assimilation, if we are going to change the relationship between Indigenous peoples and settler society. Furthermore, the alignment with these decolonizing projects should be done in a way that questions the power relationships that exist between mainstream academia and Indigenous peoples. Thus, we should ask ourselves how safe Indigenous students, faculty members, and staff feel in our classrooms and institutions at large, and how their cultural location, values, and preferences are taken into account in these places (Ball, 2008). In that sense, cultural safety calls for a transformative change in the systems of education, health, justice, and so on that begins with the recognition of the colonial violence and its continuous impacts today: "Ultimately, cultural safety demands an examination of Indigenous peoples' power in society as a whole ... it upholds the political ideas of selfdetermination and decolonization (National Aboriginal Health Organization, 2006)" (Yeung, 2016, p. 4). In the next section, we offer more concrete examples of "how to get better at it", by presenting some of the key principles that we apply in our classrooms in order to create a safe space. 
International Journal of Child, Youth and Family Studies (2019) 10(1): 95-118

\section{How the RIV Framework Can Be Applied in the Classroom}

In an effort to address the application of the RIV's four core principles to the teaching of colonial history, each author will describe her efforts to teach colonial histories that centre Indigenous pedagogies and knowledges. Both are educators with experience teaching Indigenous histories, theories, and contemporary social issues. Elizabeth is of Métis and Mennonite (settler) ancestry from St. François-Xavier, Manitoba, on Treaty 1 territory, and she is a professor in the Applied Human Sciences Department of Concordia University, where she has taught a variety of courses, including a special topics course on Indigenous perspectives across the disciplines. She is also currently in a two-and-a-half year mandate as Special Advisor to the Provost on Indigenous Directions. Marie-Ève is of French Canadian (settler) ancestry and was born and raised on Haudenosaunee territory, in Montreal (in Mohawk, Tiohtià:ke); she is a $\mathrm{PhD}$ candidate in the Sociology and Anthropology Department of Concordia University, where she is teaching the "First Peoples of North America" anthropology course. We both feel that our pedagogies and the content of our courses align with the RIV core principles of revealing truths, clarifying responsibility, revealing the resistance, and aligning with the survivors.

\section{Revealing Truths}

Elizabeth: At a recent event an educator approached me after a talk I had given and said that she was teaching a new course on "Indigenous revitalization", but that she was having difficulty because her students had no idea why Indigenous peoples needed "revitalizing". Since the release of the TRC final report in particular, I have heard increasing criticism, both among Indigenous communities and settlers, about the dangers of focusing only on stories of victimization and colonization. I wholeheartedly agree with this sentiment; however, any understanding of our contemporary realities needs to be based on a solid understanding of all that has come before us. Taking Indigenous ways of knowing and making it a central part of any course will certainly add value regardless of whether or not students have the ability to put this information into context. However, providing a balanced understanding of Indigenous knowledges, and the many ways these have been targeted by colonial projects will provide a more complete and certainly a more socially just framework for analysis.

There are many ways to introduce students to Canada's assimilationist strategies, but Indigenous pedagogies call for holistic and embodied ways of learning these histories. On several occasions I have invited facilitators of the "Blanket Exercise" by Kairos ${ }^{3}$ to take students through this hour-long experiential activity. The activity takes students through 500 years of colonial history while they role-play being part of Indigenous communities that see their land (blankets) shrink before their eyes and see children removed from their arms. They then hear about some of the current impacts and ways that Indigenous peoples have resisted ongoing incursions onto their lands and into their lives. For many students, particularly in the context of eastern Quebec

\footnotetext{
${ }^{3}$ https://www.kairosblanketexercise.org/
} 
university classes, this is their first exposure to these truths about Canada's treatment of Indigenous peoples. The facilitators allow time for a talking circle at the end of the activity in order to give students a chance to process the reactions they may experience, including guilt, shame, anger, and sadness. Most, if not all, students have written about the profound impact that this activity has had in leading them to think differently about the myth of Canada as a just nation. They also write about their new understanding of their own role in helping to reveal these truths to their own friends and family members, now that they have received this education.

Another way of including first person accounts of colonial projects is to use films that allow students to hear from Indigenous survivors of residential schools. The NFB film "We were children"4 provides emotionally charged accounts of the realities of being taken from one's family, the explicit attempts made by the government and church employees to eradicate Indigenous cultures, and the ongoing intergenerational impacts of these abuses. The NFB provides debriefing materials that educators can use to help students work through their feelings after viewing the film. Other activities that help them process these topics are reflective writing and talking to other students who are experiencing similar emotions.

When educators are learning this information for the first time along with their students, it may be threatening to include these kinds of activities. There may need to be greater efforts to make activities available specifically for faculty development. Alternatively, Regan (2010) suggests approaching learning about colonial histories and Indigenous knowledges with great humility. Approaching teaching as a "co-learner" is consistent both with Indigenous pedagogies and collaborative learning approaches (Barkley, Cross, \& Major, 2014; Kanu, 2006).

Marie-Ève: This idea of humility is fundamental, and in the classroom, I try to set an example out of my own position and experience. I begin my course by presenting how I am a settler in Mohawk territory, a fact that I was unaware of for most of my life. While I am careful to situate that ignorance is not innocence, I do encourage my students to reflect on their own positionality, to consider from where they have come to "knowledge", and to begin seeing some of the gaps that might have existed in their education. Furthermore, I tend to structure my course so that the first part of the semester is dedicated to understanding the colonial context in which anthropology was developed as a discipline, and how it still plays a role as an "expert knowledge" in the actual colonial system. We question our own categories of knowledge during that first part of the course, and we also discuss how these categories often obscure or erase Indigenous knowledges, histories, and experiences. I include in these discussions works and videos on Indigenous literary forms, scientific knowledges, and architecture and urbanism, and on how colonial processes destroyed, marginalized, and continue to invisibilize these knowledges.

In the second part of the course, we engage with current issues for Indigenous peoples such as land, education, identity, nationhood, and self-determination. For each of these issues, I include

\footnotetext{
${ }^{4}$ https://www.nfb.ca/film/we were children/trailer/we were children trailer/
} 
texts and activities that take into account the colonial legacy and ongoing violence, alongside texts and activities that help with thinking critically about decolonization, and that present Indigenous proposals and knowledges around these issues. Understanding the Doctrine of Discovery as a colonial tool and the basis for the legitimacy of the Canadian state is a priority in my class. The Blanket Exercise that Elizabeth mentions will be part of my course for the first time this semester, replacing my lecture on the issue of land. The course includes films and testimonies of residential schools survivors on the issue of education, as Elizabeth suggests, as well as a "field trip" to the Kanien'kehá:ka Onkwawén:na Raotitióhkwa Language and Cultural Center in Kahnawake ${ }^{5}$, who agreed to host my class. A presentation by a community member situated the centre's programs, including its efforts in language revitalization, in the context of the community's history. This presentation, together with the exhibits in the centre's museum, had a great impact on the students. The exhibits covered colonial history up to the present, with highlights on the St. Lawrence Seaway's impact on the community, and on the "Oka Crisis" events. For many students, it was the first time they had visited an Indigenous community in a conscious way, and the testimony and history they heard that day made concrete many of the issues we had talked about in class.

\section{Clarifying Responsibility}

Elizabeth: As students move through different phases of learning about their own relationship to oppression in society, there are some activities that can get them to consider their own level of privilege. The exercise "Unpacking the Invisible Backpack" by Peggy McIntosh (1989) is one such activity that can be adapted for use among diverse groups of students. The activity has several variations, ranging from stepping forward or back for each privilege the students have experienced, to a more private version where the students individually keep track of their own level of privilege. Once again, it is important to allow everyone to debrief after this activity, as some of the statements deal with intergenerational traumas or touch on topics that students may never have thought of as having a direct impact on their lives.

When students begin to understand their own privilege, they become better able to take responsibility. Responsibility does not mean that the students take the blame for Canada's colonial legacy, but rather that they are grounded in the reality that there are ongoing ways that colonization is acting in the lives of Indigenous people, that they have the responsibility to learn about these histories, and that they have the responsibility not to commit the same mistakes as past generations in whatever profession they follow. Additionally, responsibility means that if they want to be useful as an "ally" they must build real relationships with Indigenous people and commit to whatever actions they choose to take with great care and humility.

Marie-Ève: While I also bring into the classroom the idea of individual privilege in relation to the society's structure, and especially in terms of problematizing settlers' privileges (Irlbacher-Fox, 2014), I address them in parallel with a "Western privilege" or the construction of

\footnotetext{
${ }^{5}$ http://www.korkahnawake.org/
} 
International Journal of Child, Youth and Family Studies (2019) 10(1): 95-118

a "Western intellectual tradition" (see, e.g., Williams, 2012a) and its participation in the racial and colonial privilege, or, as Kuokkanen calls it, "the white supremacy of intellectual conventions that manifest themselves as discriminatory practices and discourses, both of which have real-life effects" (Kuokkanen, 2007, p. 65). Battiste (2013) also talked of a displacement from biological racism to cognitive racism. This is the kind of racism that we address in the classroom when I ask my students to reflect on the theoretical perspectives they privilege as "valid knowledge". We look at different maps to see the direct impacts of anthropological theorization regarding Indigenous peoples (through "cultural areas", "linguistic families", etc.) on their representations, when compared to Indigenous maps of their own nations and territories. I also use what I call an epistemological exercise for students to reflect on "how they know what they know". I present a closed box to the class and ask them how would they proceed to know what is in the box from where they are sitting, including possibly creating tools, and so on. Then we debrief on what their answer means in terms of their ontological and epistemological assumptions, and we think about privileged epistemologies and knowledges in our institution.

Just as Elizabeth mentions, responsibility does not entail blaming students for privileging Western ways of knowing, and quite often ignoring Indigenous ways of knowing, but instead requires us to understand where each of us stands, and assume this position together with the choice to critically analyze the privilege of Western knowledge and to challenge this privilege by entering in conversation with Indigenous knowledges. Similarly, while we cover extensively the relation of anthropology to colonialism, both in the history of the discipline and in its current role in our society, the idea is not to discard anthropology or blame students for engaging in that discipline, but, rather, to raise awareness of some of the problems and critiques of the discipline. Furthermore, by engaging with Indigenous anthropologists such as Charles Menzies, Kim TallBear, and Audra Simpson, amongst others, the critical stance is balanced with the hope of doing anthropology differently.

\section{Revealing Resistance}

Elizabeth: Teaching about resistance means moving away from focusing on Indigenous peoples in the role of victims to highlighting the multiple acts of resistance that are happening across the globe. Once learners have a solid understanding of the colonial mentality, they will be ready to understand both the terminology and the necessity of concepts such as cultural revitalization, self-determination, and self-governance. These should not merely be taught as reactions to colonization, but rather as ever-present entities that have seen ruptures, but continue to live on and flourish (Vizenor, 2008).

This also means highlighting Indigenous ways of learning, which include a wide range of "nontraditional" or rather, non-Western, practices. Every semester my students take part in a number of these activities, including field trips, guest speakers, and using stories as learning tools, along with activities that incorporate multiple learning styles (Kanu, pg. 7). One field trip to a local community consisted of a presentation by a community-run organization that offered a wide range 
of activities and health and healing opportunities to their constituents. The presentation highlighted the ways that the community has taken control of their own well-being, resisting government limitations by being creative and assertive in their attainment of funds, and by being inclusive of diverse needs within the community by offering both western and Indigenous opportunities for healing and for maintaining mental health.

We have also visited an urban Indigenous social enterprise, as well as had guest speakers who are advocates for ethical and community-based collaborations with local Indigenous communities. Finally, using Indigenous authors and films ensures that any interpretations or analyses are launched from the lived experiences of Indigenous peoples and will stay away from outsider- or "victimization"-focused accounts of one-sided abuse by the government.

Marie-Ève: The use of Indigenous authors and films is indeed fundamental in my class too. The first time I taught the class, the format was a twice-weekly hour-and-a-half meeting. I had consequently structured my class so that we would look at issues from three perspectives. The first meeting, we would look at either the colonial legacy or Western concepts and knowledges, often from a critical standpoint. At the second meeting, we would look at Indigenous perspectives and knowledges on the same issues. This was a great way to balance the colonial violence of the first meeting, and not perpetuate it by maintaining Indigenous peoples as victims, but rather, show how different Indigenous nations, practitioners, and intellectuals had various strategies to resist the colonial violence, and different solutions to problems of our society. The next time I taught the course, it had been reorganized as a three-hour weekly meeting. Given that many students complained that I was assigning too many readings, I had to change the format, but we still are looking at one perspective on colonial legacy and ongoing violence, one decolonization perspective (that can be from an Indigenous author, but mainly, a critical stance), and one Indigenous perspective on the subject, meaning one proposal that is rooted in an Indigenous intellectual tradition (not necessarily a critical stance). While less detailed and varied, this solution still allows for the presentation of Indigenous resistance and survivance. I also end my course with looking at Indigenous national and international activism, diplomacy, and resistance through history, from Tecumseh's movement to Idle No More, going through the interventions of Indigenous peoples at the United Nations and in the national politics of various countries.

\section{Aligning with the "Victim" and Increasing Cultural Safety}

Elizabeth: Teaching difficult material requires that educators think carefully about how they will handle "microaggressions" and racist or inadvertently ignorant comments. Thinking carefully about setting up cultural safety in the classroom will ultimately make a difference in whether Indigenous students either learn from or feel further stigmatized by learning about Canada's abusive relationship with Indigenous Nations (Cote-Meek, 2013). At the beginning of the semester, I make it clear that students come into the classroom with very different levels of knowledge about Indigenous issues and peoples. Students with a low level of knowledge or lived experience are encouraged to listen much more than they speak and to do their own self-learning 
International Journal of Child, Youth and Family Studies (2019) 10(1): 95-118

by using at least three sources to try to find the "answer" to their query before asking me (the "three before me" rule). I also make it clear that I will address comments that I interpret as microaggressions, racist, or ignorant, and encourage students to do the same, as long as we do so respectfully (Battiste, 2013; Barkley et al., 2014).

Students are also asked to group themselves by their level of knowledge or lived experience and encouraged to work in groups where they feel most comfortable. For many Indigenous students and others who have spent a lot of time listening and learning, this will keep them from always having to backtrack and answer basic questions that newer learners might be struggling with. For newer learners, this gives them the space to gain a better understanding, without worrying about inadvertently insulting others. This model does not, however, mean that these students will not have to take some risks. Groups are expected to present their ideas to the larger class at various intervals and may have to have some of their interpretations or comments addressed by myself or other members of the class.

Marie-Ève: I am learning a lot from Elizabeth's take on cultural safety in the classroom, and this year I adopted her idea of forming groups by level of knowledge and experiences. In regard to aligning with the survivors, I have used some tools that I thought were useful in terms of creating empathy in non-Indigenous learners. Pringle and Featherstone's (1986) short film Babakiueria presents an Australian Aboriginal satire of colonialism, inverting the roles of White and Aboriginal societies in Australia with an Aboriginal anthropologist commenting on Western ways of living. By reversing the mirror, this film seems to have a great impact on students. Similarly, Deloria's (1969) Anthropologists and Other Friends text helps students in anthropology understand the Indigenous perspective on anthropological research. Finally, making space to critically discuss colonialism, while centring the class on Indigenous resistance to it and Indigenous knowledges and histories from their own perspectives, has also created space for Indigenous students to be proud of their experiences and cultures. I also encountered this in the journals of other students, non-Indigenous but from non-Western backgrounds, who felt they also had space to engage with their own legacy and its relation to colonialism.

\section{Conclusion}

When beginning this article, we thought it would be interesting and useful to try applying the RIV framework to the broader systemic and societal violence of historical and ongoing colonialism in Canada. With the recommendations of the TRC in mind, we thought that the RIV framework could be useful in establishing principles for educators to follow when teaching colonial histories and addressing colonial violence in their classrooms. Along the way, we also became more conscious that the principles of the RIV framework had quite often already put forward by Indigenous academics, intellectuals, and educators. Thus, we decided to first establish a dialogue between the RIV framework and Indigenous and decolonizing pedagogies and knowledges. The outcome is a set of models that we can follow, as educators, to address colonial 
histories while also recognizing Indigenous resistance to this violence and aligning our practices with Indigenous survivance.

Perhaps because of our engagement in, and commitment to, Indigenous pedagogies and knowledges, we have both come to the realization while writing this article that our teachings have been aligned with the core principles of the RIV framework. We are sure that many other educators, especially Indigenous educators and non-Indigenous allies, might already practice these core principles. However, this explicit reflection on our pedagogy in relation to the RIV framework might help other teachers and educators to improve their teaching of colonial histories by following the four core principles of truth-telling, taking responsibility, acknowledging and learning from Indigenous resistance, and aligning with Indigenous survivors. We hope that our concrete examples, taken from our respective teaching experiences, will serve as stepping stones for colleagues who might want to undertake the task of addressing colonial histories in their classrooms.

This model may also help to recontextualize discussions of Indigenizing the academy by providing a clear framework for ethically moving forward. The problems with the discourse of reconciliation have been clearly highlighted here, particularly in regard to the last two core points - acknowledging and learning from resistance, and aligning with survivors — and some solutions have been offered. 
International Journal of Child, Youth and Family Studies (2019) 10(1): 95-118

\section{References}

Alfred, T., \& Corntassel, J. (2005). Being Indigenous: Resurgences against contemporary colonialism. Government and Opposition, 40(4), 597-614. doi:10.1111/j.14777053.2005.00166.x

Ball, J. (2007). As if Indigenous knowledge and communities mattered: Transformative education in First Nations communities in Canada. The American Indian Quarterly, 28(3\&4), 454-479. doi:10.1353/aiq.2004.0090

Ball, J. (2008). Promoting equity and dignity for Aboriginal children in Canada. Institute for Research on Public Policy (IRPP) Choices, 14(7), 1-30.

Barkley, E. F., Cross, K. P., \& Major, C. H. (2014). Collaborative learning techniques: A handbook for college faculty. Hoboken, NJ: John Wiley \& Sons.

Battiste, M. (1998). Enabling the autumn seed: Toward a decolonized approach to Aboriginal knowledge, language, and education. Canadian Journal of Native Education, 22(1), 16-27.

Battiste, M. (2013). Decolonizing education: Nourishing the learning spirit. Saskatoon, SK: Purich Publishing.

Bigelow, B., \& Peterson, B. (Eds.). (1998). Rethinking Columbus: The next 500 years. Milwaukee, WI: Rethinking Schools.

Brayboy, B. M. J. (2005). Toward a tribal critical race theory in education. The Urban Review, 37(5), 425-446. doi:10.1007/s11256-005-0018-y

Canadian Association of University Teachers (CAUT)/ Association canadienne des professeures et professeurs d'université (ACPPU). (2016). Indigenizing the academy: The way forward. CAUT ACPPU Bulletin, 63(6), A1-A5.

Coates, L., \& Wade, A. (2007). Language and violence: Analysis of four discursive operations. Journal of Family Violence, 22, 511-522. doi:10.1007/s10896-007-9082-2

Chi'XapKaid, M. P. (2005). Decolonizing through storytelling. In A. W. Waziyatawin \& M. Yellow Bird (Eds.), For Indigenous eyes only: A decolonization handbook (pp. 127-137). Santa Fe, NM: School of American Research.

Corntassel, J. (2012). Re-envisioning resurgence: Indigenous pathways to decolonization and sustainable self-determination. Decolonization: Indigeneity, Education \& Society, 1(1), 86101.

Cote-Meek, S. (2014). Colonized classroom. Racism, trauma and resistance in post-secondary education. Halifax, NS: Fernwood. 
International Journal of Child, Youth and Family Studies (2019) 10(1): 95-118

Deloria, V. J. (1969). Anthropologists and other friends. In V. J. Deloria, Custer died for your sins: An Indian manifesto (pp. 78-100). London, UK: Collier-Macmillan.

Dion, S. D. (2007). Disrupting molded images: Identities, responsibilities and relationshipsteachers and indigenous subject material. Teaching Education, 18(4), 329-342. doi:10.1080/10476210701687625

Ermine, W. J. (2007). The ethical space of engagement. Indigenous Law Journal, 6(1), 193-203.

Evans-Campbell, T. (2008). Historical trauma in American Indian/Native Alaskan communities: A multilevel framework for exploring impacts on individuals, families, and communities. Journal of Interpersonal Violence, 23(3), 316-337. doi:10.1177/0886260507312290

Fast, E., \& Nutton, J. (2014). Draft guidelines for determining Indigenous identity for child welfare workers. Montreal, QC: Centre for Research on Children and Families, McGill University.

Frichner, T. G. (2010). The "preliminary study" on the Doctrine of Discovery. Pace Environmental Law Review, 28(1), 339-345.

García, J., Lozano, A., Olivera, J., \& Ruiz, C. (Eds.). (2004). Sumak yachaypi alli kawsaypipash yachakuna $=$ Aprender en la sabiduría y el buen vivir = Learning wisdom and the good way to live. Quito, Ecuador: Universidad Intercultural Amawtay Wasi \& UNESCO.

Grande, S., San Pedro, T., \& Windchief, S. (2015). 21st century Indigenous identity location: Rememberance, reclamation, and regeneration. In D. Koslow \& L. Sallet (Eds.), Multicultural perspectives on race, ethnicity, and identity (pp. 105-122). Washington, DC: NASW Press.

Henry, E. (2014). A search for decolonizing place-based pedagogies: An exploration of unheard histories in Kitsilano Vancouver, B.C. Canadian Journal of Environmental Education, 19, $18-30$.

Irlbacher-Fox, S. (2014). Traditional knowledge, co-existence and co-resistance. Decolonization: Indigeneity, Education \& Society, 3(3), 145-158.

Kanu, Y. (2006). Integrating Aboriginal perspectives into the school curriculum: Purposes, possibilities, and challenges. Toronto, ON: University of Toronto Press.

Kinewesquao, \& Wade, A. (2009). Taking resistance seriously: A response-based approach to social work in cases of violence against Indigenous women. In S. Strega \& S. A. Esquao (Eds.), Walking this path together: Anti-racist and anti-oppressive child welfare practice (pp. 204-220). Winnipeg, MB: Fernwood. 
International Journal of Child, Youth and Family Studies (2019) 10(1): 95-118

Kovach, M., Carriere, J., Montgomery, H., Barrett, M. J., \& Gilles, C. (2015). Indigenous presence: Experiencing and envisioning Indigenous knowledges within selected postsecondary sites of education and social work [Report]. Retrieved from http://www.usask.ca/education/documents/profiles/kovach/Indigenous-Presence-2014Kovach-M-et-al.pdf

Kuokkanen, R. (2007). Reshaping the university. Responsibility, Indigenous epistemes, and the logic of the gift. Vancouver, BC: University of British Columbia Press.

Lomawaima, T. (1999). The unnatural history of American Indian education. In J. W. Tippeconnic \& K. Gayton Swisher (Eds.), Next steps. Research and practice to advance Indian education (pp. 1-32). Charleston, SC: Eric.

Lomawaima, T., \& McCarty, T. (2006). To remain an Indian: Lessons in democracy from a century of Native American education. New York, NY: Teachers College Press.

MacDonald, M. (2016, April 6). Indigenizing the academy. What some universities are doing to weave Indigenous peoples, cultures and knowledge into the fabric of their campus. University Affairs/Affaires universitaires. Retrieved from http://www.universityaffairs.ca/features/feature-article/indigenizing-the-academy/

McCarthy, T. L., \& Lee, T. S. (2014). Critical culturally sustaining/ revitalizing pedagogy and Indigenous education sovereignty. Harvard Educational Review, 84(1), 101-124. doi:10.17763/haer.84.1.q83746n15pj34216

McIntosh, P. (1989). White privilege: Unpacking the invisible knapsack. Peace and Freedom Magazine, July-August, 10-12.

Miller, R. J. (2011). The international law of colonialism: A comparative analysis. Lewis \& Clark Law Review, 15(4), 847-922.

Miller, R. J., Ruru, J., Behrendt, L., \& Lindberg, T. (2012). Discovering Indigenous lands: The Doctrine of Discovery in the English colonies. Oxford, UK: Oxford University Press.

Milloy, J. (1996). A national crime: The Canadian government and the residential school system - 1879 to 1986. Winnipeg, MB: University of Manitoba Press.

Murphy, H., \& Robitaille, N. (2015, June 29). Universities Canada principles on Indigenous education [Press release]. Universities Canada. Retrieved from http://www.univcan.ca/media-room/media-releases/universities-canada-principles-onindigenous-education/

Newhouse, D. (2016). The meaning of Indigenization of our universities. CAUT ACPPU Bulletin, 63(6), A2-A7. 
International Journal of Child, Youth and Family Studies (2019) 10(1): 95-118

Pringle, J. (Producer), \& Featherstone, D. (Director). (1986). Babakiueria [TV short]. Australia: Australian Broadcasting Corporation.

Regan, P. (2010). Unsettling the settler within: Indian residential schools, truth telling, and reconciliation in Canada. Vancouver, BC: University of British Columbia Press.

Snelgrove, C., Kaur Dhamoon, R., \& Corntassel, J. (2014). Unsettling settler colonialism: The discourse and politics of settlers, and solidarity with Indigenous nations. Decolonization: Indigeneity, Education \& Society, 3(2), 1-32.

Truth and Reconciliation Commission of Canada (TRC). (2015). Calls to action. Winnipeg, MB: Author. Retrieved from http://nctr.ca/assets/reports/Calls_to_Action_English2.pdf

Tuck, E., \& Yang, K. W. (2012). Decolonization is not a metaphor. Decolonization: Indigeneity, Education \& Society, 1(1), 1-40.

UN Permanent Forum on Indigenous Issues. (2010). Impact on Indigenous Peoples of the international legal construct known as the Doctrine of Discovery, which has served as the foundation of the violation of their human rights. New York, NY: United Nations Economic and Social Council. Retrieved from http://www.un.org/esa/socdev/unpfii/documents/E.C.19.2010.13\%20EN.pdf

UN Permanent Forum on Indigenous Issues. (2012). Report on the Eleventh Session. New York, NY: United Nations Department of Economic and Social Affairs.

Urrieta, L., Jr. (2013). Familia and comunidad-based saberes: Learning in an Indigenous heritage community. Anthropology \& Education Quarterly, 44(3), 320-335. doi:10.1111/aeq.12028

Vizenor, G. (2008). Aesthetics of survivance: Literary theory and practice. In G. Vizenor (Ed.), Survivance: Narratives of Native presence (pp. 1-24). Lincoln, NB: University of Nebraska Press.

Waziyatawin, A. W. (2005). Relieving our suffering: Indigenous decolonization and United States Truth Commission. In A. W. Waziyatawin \& M. Yellow Bird (Eds.), For Indigenous eyes only: A decolonization handbook (pp. 189-205). Santa Fe, NM: School of American Research.

Waziyatawin, A. W., \& Yellow Bird, M. (2005). Beginning decolonization. In A. W. Waziyatawin \& M. Yellow Bird (Eds.), For Indigenous eyes only: A decolonization handbook (pp. 1-7). Santa Fe, NM: School of American Research.

Wildcat, M., McDonald, M., Irlbacher-Fox, S., \& Coulthard, G. (2014). Learning from the land: Indigenous land based pedagogy and decolonization. Decolonization: Indigeneity, Education \& Society, 3(3), I-XV. 
International Journal of Child, Youth and Family Studies (2019) 10(1): 95-118

Williams, R. A. (1988). Learning not to live with Eurocentric myopia: A reply to Professor Laurence's Learning to live with the plenary power of Congress over the Indian Nations. Arizona Law Review, 30, 440-457.

Williams, R. A. (1990). The American Indian in Western legal thought. The discourses of the conquest. Oxford, UK: Oxford University Press.

Williams, R. A. (2012a). Savage anxieties. The invention of Western civilization. New York, NY: Palgrave Macmillan.

Williams, R. A. (2012b). What the hell happened to Mabo? The search for the missing link. In T. Bauman \& L. Glick (Eds.), The limits of change: Mabo and native title 20 years on (pp. 2440). Canberra, Australia: AIATSIS Research Publications.

Yeung, S. (2016). Conceptualizing cultural safety: Definitions and applications of safety in health care for Indigenous mothers in Canada. Journal for Social Thought, 1(1), 1-13. 